\title{
Selenium mobilization in soils due to volcanic derived acid rain: An example from Mt Etna volcano, Sicily
}

\author{
G.H. Floor ${ }^{\text {a,b,* }}$, S. Calabrese ${ }^{\text {c,d }}$, G. Román-Ross ${ }^{\text {a,e }}$, W. D’Alessandro ${ }^{\text {d }}$, A. Aiuppa ${ }^{\text {c,d }}$ \\ a University of Girona, Dep. Chemistry, Campus de Montilivi s/n, 17071, Girona, Spain \\ b BRGM; Sec. Metrology, Monitoring, Analysis, BP 45060 Orleans, France \\ ' University of Palermo, Dept. DiSTeM, via Archirafi 36, 90123 Palermo, Italy \\ d Istituto Nazionale di Geofisica e Vulcanologia, sezione di Palermo, via Ugo La Malfa 153, 90146 Palermo, Italy \\ e Amphos 21 Consulting S. L. Passeig de Garcia i Faria 49, 08019 Barcelona, Spain
}

\section{A R T I C L E I N F O}

\section{Article history:}

Received 10 September 2010

Received in revised form 30 July 2011

Accepted 8 August 2011

Available online 19 August 2011

Editor: J. Fein

\section{Keywords:}

Selenium

Volcanic soils

Geogenic

Volcanoes

Contamination

Groundwater

\begin{abstract}
A B S T R A C T
The significant amounts of selenium (Se) emitted by volcanoes may have important impact on human health due to the narrow range between nutrition requirement and toxic effects for living organisms upon Se exposure. Although soils play a key role in determining the level in food and water and thereby human health, little is known about the behaviour of Se in volcanic soils. In this work we evaluated the Se release during rainwater-soil interaction under controlled conditions using soils collected on the flanks of Etna volcano and synthetic rain. Selenium concentrations in soil leachate solutions displayed a spatial distribution, which cannot be explained by plume deposition, total Se soil concentrations or the presence of Fe oxides. Instead, Al compounds and to a minor extent SOM were identified as the active phases controlling the selenate mobilization during interaction with sulphate-containing rainwater. This shows the importance of soils as reactive interfaces. Selenium is mobilized when volcanic-derived acid rain interacts with poorly developed soils close to the crater. This geogenic process might influence the chemical composition of groundwater and as a result, human health.
\end{abstract}

(c) 2011 Elsevier B.V. All rights reserved.

\section{Introduction}

Volcanoes are an important natural source of selenium (Se). Selenium is an essential element, but can be toxic too, depending on its concentration with a relatively narrow safe intake range from 40 ro $400 \mu \mathrm{g} /$ day (Rayman, 2000). Selenium is volatilized in the magmatic plumbing system and as a result tens of kilograms Se per day might be released by a single volcano (Faivre-Pierret and Le Guern, 1983; Hinkley et al., 1999; Allen et al., 2000; Aiuppa et al., 2003a). Nevertheless, the chemical fate of Se around volcanoes is poorly constrained as Se emissions have been only studied for a few volcanoes (Mather et al., 2003). Selenium speciation measurements in volcanic plumes are not available, but high temperature thermodynamic models and the comparison with coal combustion suggest the presence of $\mathrm{H}_{2} \mathrm{Se}$, elemental Se and $\mathrm{SeO}_{2}$ (Suzuoki, 1964; Symonds and Reeds, 1993; Monahan-Pendergast et al., 2008). Oxidation and cooling processes in the atmosphere will transform this $\mathrm{Se}$ to soluble selenite $\left(\mathrm{SeO}_{3}^{2-}\right)$ and selenate $\left(\mathrm{SeO}_{4}^{2-}\right)$ (Wen and Carignan, 2007). As a result, rainwater close

\footnotetext{
* Corresponding author currently at: EC-Joint Research Centre- Institute for Reference Materials and Measurements, Retieseweg 111, 2440 Geel, Belgium. Tel.: + 34619935580. E-mail addresses: Geerke.FLOOR@ec.europe.eu, geerke.floor@aquatrain.eu (G.H. Floor).
}

to volcanoes might be significantly enriched in Se. For example, concentrations in Etnean rainwater have been reported to be up to $13 \mu \mathrm{g} / \mathrm{kg}$ (Calabrese, 2009; Calabrese et al., submitted; Table 1). Additionally, this interaction between volcanic gases and atmospheric water causes huge variations in rainwater $\mathrm{pH}$ (from 2 to 7 ), both in space (km scale) and time (weeks-months; Aiuppa et al., 2006). However, the environmental impact of this Se flux from the volcano towards the aquifer strongly depends on processes in the soils.

Soils formed in volcanic areas have distinctive properties that are rarely found in soils derived from other parent materials, such as a variable electrical charge and a high anion exchange capacity (Shoji et al., 1993). Moreover, soils around volcanoes are exposed to extreme environmental conditions, including direct plume fumigation, acid rain (Delmelle et al., 2001, 2003; Bellomo et al., 2007) and fresh ash input (Agnelli et al., 2007; Egli et al., 2007), which cause strong physicochemical gradients upwind and downwind from the volcano. Although volcanic soils only occupy around $1 \%$ of the terrestrial surface, they host $10 \%$ of the worldwide population (Small and Naumann, 2001). They can have high Se concentrations (e.g. 6-15 mg/kg in Hawaii compared to $0.4 \mathrm{mg} / \mathrm{kg}$ as worldwide average), but in contrast show low Se mobility (Byers et al., 1938; John et al., 1975; Nakamaru et al., 2005). This low mobility is believed to originate from adsorption on Fe and Al minerals (John et al., 1975; Nakamaru et al., 2005), which have been widely reported as potential adsorption phases for Se (Balistrieri and Chao, 
Table 1

Important characteristics of Etnean rainwater. Data from Calabrese, 2009. Negative distance means downwind from the craters.

\begin{tabular}{lllllll}
\hline \multicolumn{2}{l}{ Distance to craters $(\mathrm{km})$} & -7.3 & 1.2 & 5.5 & 6.5 & 9.9 \\
$\mathrm{pH}$ & Max & 7.1 & 4.9 & 6.9 & 7.1 & 7.0 \\
& Min & 3.4 & 2.0 & 2.6 & 3.0 & 3.5 \\
& Mean & 5.6 & 3.7 & 4.2 & 5.0 & 5.2 \\
$\mathrm{SO}_{4}^{2-}(\mathrm{mg} / \mathrm{L})$ & Max & 31.5 & 446 & 84.9 & 59.8 & 18.3 \\
& Min & 1.20 & 1.74 & 1.87 & 1.08 & 0.65 \\
& Mean & 6.79 & 81.44 & 12.72 & 9.78 & 7.01 \\
$\mathrm{Se}(\mu \mathrm{g} / \mathrm{L})$ & Max & 0.62 & 13.09 & 4.59 & 1.48 & 1.40 \\
& Min & 0.02 & 0.45 & 0.05 & 0.06 & 0.05 \\
& Mean & 0.27 & 3.63 & 0.91 & 0.47 & 0.47 \\
\hline
\end{tabular}

1990; Dynes and Huang, 1997; Parida et al., 1997; Wijnja and Schulthess, 2000; Duc et al., 2003; Peak et al., 2006; Fernández-Martínez and Charlet, 2009). Although soils play a key role in determining the level in food and water and thereby human health, the knowledge about the processes affecting the Se mobility in volcanic soils is limited.

Mount Etna is the largest active volcano in Europe and has been persistently active over the past few thousand years. It is among the most intensely monitored volcanoes of the world (Bonaccorso et al., 2004) and is one of the few volcanoes for which Se flux has been estimated (Aiuppa et al., 2003a). Selenium contents have also been studied in rainwater (Calabrese, 2009; Calabrese et al., submitted) and in groundwater (Giammanco et al., 1996; Brusca et al., 2001; Aiuppa et al., 2003b). However, the contents and chemical fates of Se within Etnean soils are unknown. For these reasons, Mount Etna is an excellent geochemical field site to study the behaviour of Se in soils and specifically during soil-rainwater interaction.

The Etnean aquifers, the only water resource for about one million inhabitants around Mount Etna, are enriched in Se. Concentrations up to $66 \mu \mathrm{g} / \mathrm{L}$ have been reported, which is above the WHO guideline of $10 \mu \mathrm{g} /$ L. Aiuppa et al. (2000) estimated that the aquifers discharge around $2 \mathrm{t} / \mathrm{a}$ Se. Several studies (Giammanco et al., 1996, 1998; Aiuppa et al., 2000, 2003b; Brusca et al., 2001) identify three main sources for trace elements: (a) the leaching of the host basalt, driven by the dissolution of magma derived $\mathrm{CO}_{2}$ which lowers the water $\mathrm{pH}$ and therefore enhances weathering; (b) mixing processes with saline brines rising from the sedimentary basement below Etna; and (c) contamination from agricultural and urban wastewaters. However, rainwater could also cause a significant contribution for Se. It has been estimated that around $1.6-4.4 \mathrm{t} / \mathrm{a}$ of the Se emitted by the plume is locally deposited (Calabrese, 2009). Around 75\% of the rainwater is transported towards the aquifer (Aiuppa et al., 2000). This means that the potential rainwater Se flux towards the groundwater has the same order of magnitude as the Se discharge from the aquifer (Table 2). Nevertheless, as rainwater interacts with the soils during infiltration, adsorption and desorption processes can occur (Bellomo et al., 2003, 2007). Therefore, soilrainwater interaction will determine the magnitude of this flux. For this reason, in this study we evaluated this soil-rain interaction in lab

Table 2

Estimated Se fluxes around Mount Etna. Comparison shows similar order of magnitude for Se released by the aquifer and potential rainwater flux towards the aquifer (data in bold).

\begin{tabular}{|c|c|c|c|}
\hline Process & $\begin{array}{l}\text { Flux } \\
(\mathrm{t} / \mathrm{a})\end{array}$ & Comment & References \\
\hline Released by aquifer & 2 & $\begin{array}{l}\text { Based on } 0.69 \mathrm{~m}^{3} \text { discharge and } \\
\text { average Se content }\end{array}$ & $\begin{array}{l}\text { Aiuppa et } \\
\text { al., } 2000\end{array}$ \\
\hline Released by plume & 200 & Average for low activity & Calabrese, \\
\hline Local deposited & $\begin{array}{l}1.6- \\
4.4\end{array}$ & $\begin{array}{l}\text { Assuming } 0.8-2.2 \% \text { of plume locally } \\
\text { deposited }\end{array}$ & 2009 \\
\hline $\begin{array}{l}\text { Towards aquifer (if no } \\
\text { interaction with soils) }\end{array}$ & $\begin{array}{l}1.2- \\
3.3\end{array}$ & $\begin{array}{l}\text { Assuming all Se deposited in rain, } \\
75 \% \text { of rainwater towards aquifer }\end{array}$ & This work \\
\hline
\end{tabular}

controlled experiments with samples collected from the flank of Etna volcano and synthetic acid rainwater. The effect of changes in the rainwater composition ( $\mathrm{pH}$ and sulphate concentration) on the potential of leaching and re-adsorption was investigated in controlled conditions. Differences in Se release were linked with soil characteristics, the chemical composition of the leachates and Se speciation. The Se mobility during soil-rainwater interaction has significant implications for the aquifer, and therefore on the Se intake of the population around the volcano.

\section{Etna volcano}

Mount Etna is a large stratovolcano, covering an area of $1200 \mathrm{~km}^{2}$ and reaching an elevation of $3300 \mathrm{~m}$ high (Tanguy et al., 1997). Recent eruptions from the summits and flank vents, which occasionally interrupt passive degassing, have typically emitted lavas and tephras with hawaiitic composition ( $48 \% \mathrm{SiO}_{2}$, Tanguy et al., 1997). Etna volcano is considered to be one of the major volcanic gas emitters in the world, accounting for approximately $10 \%$ of worldwide volcanic emissions of $\mathrm{CO}_{2}$ and $\mathrm{SO}_{2}$ (Allard et al., 1997; D'Alessandro et al., 1997). Its estimated contribution to the annual atmospheric budget for alkali and heavy metals is 16-19\% during eruptive activity and $2-4 \%$ in quiescent periods (Gauthier and Le Cloarec, 1998).

The climate of the Etna area is mainly controlled by altitude, slope direction, dominant winds and geographical position. Under most atmospheric conditions, Etna's summit plume is dispersed by winds towards the SE at about the same altitude as the emission point (Bellomo et al., 2007). The altitude differences along the flanks of the volcano cause a gradual change from sub-tropical conditions at the base area to a moderate warmth in the middle and moderately cold and cold towards the higher regions. Lowest rainfall $(400 \mathrm{~mm})$ occurs at the lower SW flank, whereas maximum rainfall $(1200 \mathrm{~mm})$ occurs on east facing slopes at an altitude of 700-900 m due to cloud mass approaching mainly from the Ionian Sea in the east (Chester et al., 1985). Owing to the high permeability and irregularity of the lava, the edifice lacks a hydrographical network and $75 \%$ of the rain water directly infiltrates into the aquifer (Aiuppa et al., 2003b).

Soil development in the Mount Etna area is controlled by the parental material, age, the morphology (e.g. slope) and climate (Dazzi, 2007). Moreover, depending on volcanic activity, winds can carry and deposit abundant pyroclastic material (Egli et al., 2007). The limited amount of published soil studies in the area focusses on the relationship between vegetation and soil nature and shows that the soils have vitric properties (Certini et al., 2001; Egli et al., 2007). Soil organic matter, imogolite-type materials (proto-imogolite allophane and well-developed imogolite), oxyhydroxide contents and weathering decrease with increasing altitude (Egli et al., 2007). Agricultural cultivation over the last centuries or even millennia has modified substantial parts of the area. Most crops occur at altitudes of up to $900 \mathrm{~m}$, but chestnut and hazelnut cultivation occurs up to $1500 \mathrm{~m}$ (Dazzi, 2007). The vegetation limit varies between 1800 and $2200 \mathrm{~m}$, depending on the exposure to volcanic material and climatic conditions. In this study, most of the samples are non agricultural soils.

The only previous work conducted on the influence of the volcanic activity on soils focussed on fluorine and demonstrated that total fluorine contents fall within the typical range of undisturbed soils. Nevertheless, topsoils from the eastern, downwind sector of the volcano are typically richer in fluorine than the soils on the western, upwind flank (Bellomo et al., 2007). The contribution of pyroclastic material has a strong influence on the soil properties (Agnelli et al., 2007; Egli et al., 2007). In recent times, the largest deposition of new pyroclastic material resulted from the eruptions in 2001 and 2002-03. In 2001 pyroclastic products were dispersed almost exclusively in the SE and SSE directions reaching deposition values of up to $23 \mathrm{~kg} / \mathrm{m}^{2}$ (corresponding to about $2 \mathrm{~cm}$ thickness) along the main axis (Scollo et al., 2007). During the 2002-03 eruption the deposition of pyroclastic 


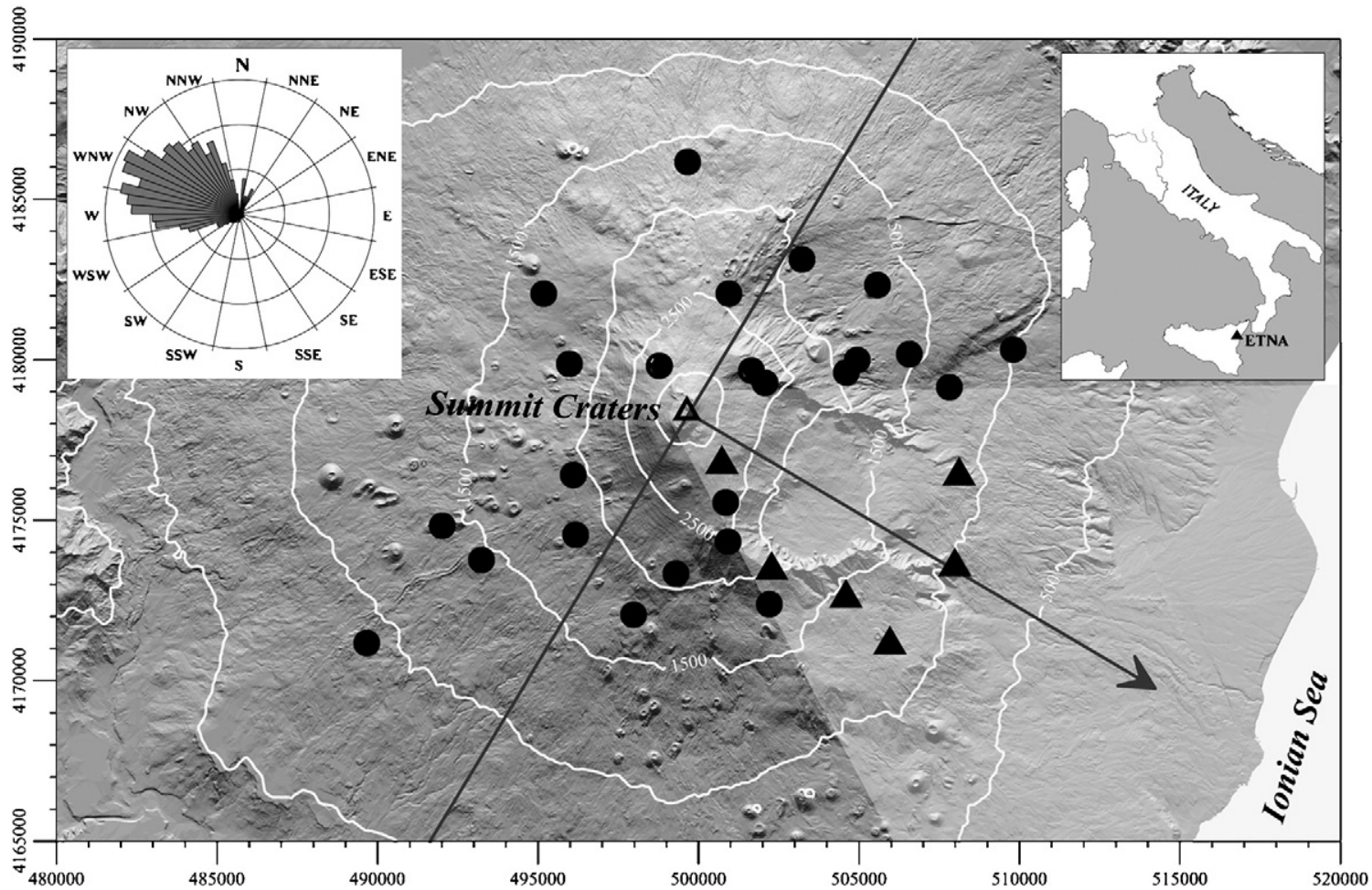

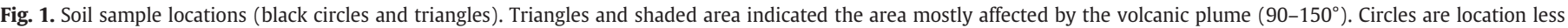

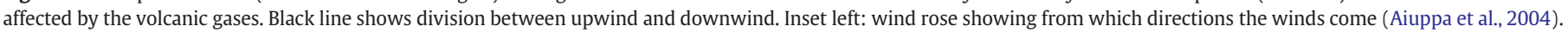
Inset right: location of Etna volcano. Open triangle indicates location of the summit craters.

material exceeded $150 \mathrm{~kg} / \mathrm{m}^{2}$ (about $10 \mathrm{~cm}$ thickness) on a large area around the emission vent ( $3 \mathrm{~km} \mathrm{~S}$ of the summit craters). Even though ashes were deposited mainly on the southern and eastern flank of the volcano, deposition also took place on the western and northern flanks (Andronico et al., 2008a). In the year prior to sampling (June 2008; Section 3) some events produced minor contribution of pyroclastic materials. The pyroclastic material derived from a lava fountain episode of the SE crater on the 4th of September 2007 covered a very narrow strip in the E direction with deposition of more than $10 \mathrm{~kg} / \mathrm{m}^{2}$ (Andronico et al., 2008b). From October until mid November 2007, ash emissions occurred infrequently. On November 22nd, 23rd and 24th 2008 explosive activity blew a dense tephra plume NE and caused ash and lapilli falls as far as $80 \mathrm{~km}$ away (Andronico and Cristaldi, 2007). An eruption that started on the 13th of May 2008 was preceded on the 10 th by a lava fountain episode at the SE crater. In this event only a small amount of pyroclastic material was emitted, but dispersed over a much broader area (INGV-Ct, 2008).

\section{Methods}

The upper $10 \mathrm{~cm}$ material (soil and/or ash) was collected at Mt Etna between 2 and $10 \mathrm{~km}$ from the craters and between 900 and $3000 \mathrm{~m}$ altitude (Fig. 1; Table A1) in June 2008. Most soils collected were natural soils, formed over relatively homogeneous hawaiitic bedrocks (essentially lava flows). However, at lower altitudes, soil samples were used for agricultural purposes. At each location, a composite sample was obtained (3 different spots, minimum distance between them $2 \mathrm{~m}$ ). Soils were air-dried, sieved (the fine earth fraction $(<2 \mathrm{~mm})$ ) and homogenised. Different aliquots of the same soil were used for acid and neutral rain experiments. Synthetic volcanic glass was made by heating and fast cooling down of one of the soils, followed by grinding.

Two simplified synthetic rainwaters were prepared based on a rainwater dataset collected around the volcano in 2006-2007 (Calabrese, 2009; Calabrese et al., submitted):
1) As proxy for neutral rain without any sulphate, pure water (Millipore corp., Bedford, MA, USA) with a pH of 6 was used. This synthetic rain is a proxy for the average upwind rain and to downwind rain during low volcanic activity (Calabrese, 2009).

2) An acid rain was made out of diluted $\mathrm{H}_{2} \mathrm{SO}_{4}$ (SpA grade MERCK) to obtain $450 \mathrm{mg} / \mathrm{kg}$ sulphate and a $\mathrm{pH}$ of 2 . The $\mathrm{pH}$ and sulphate concentration were based on the minimum and maximum values measured in rainwater samples collected in the period 2006-2007 close to the crater during increased volcanic activity (Table 2).

Batch experiments were performed at room temperature with a soilrainwater ratio of 1:5 and a contact time of $4 \mathrm{~h}$. To estimate the analytical error some of the experiments were performed in triplicates with different aliquots of the homogenised soils. After $4 \mathrm{~h}$, the $\mathrm{pH}$ and Eh values were measured in the leaching solutions. Afterwards, the solutions were centrifuged, filtered (Whatman, $0.45 \mu \mathrm{m}$ polypropylene media) and acidified with nitric acid (Romil suprapure, $\mathrm{Se}<0.1 \mu \mathrm{g} / \mathrm{kg}$ ).

Selenium and arsenic (As) concentrations in leachate solutions were determined by an ICP-MS (Agilent 7500c) equipped with a hydrogen pressurized collision cell, monitoring ${ }^{78} \mathrm{Se}$ and ${ }^{75}$ As. Both samples and standard were measured in a matrix of $2 \%$ methanol ( $\mathrm{MeOH}>99.9 \%$ pure, chromosolv plus, Sigma-Aldrich) added prior to analyses in order to increase sensitivity (Floor et al., 2009). To compensate for matrix effects Rh was added as internal standard. Major elements in leachate solutions were measured by ICP-AES. In order to evaluate the contribution of the dissolution of volcanic glass to the major element composition in the leachates, a synthetic acid rain-volcanic glass experiment was performed in the same way as for the soils. The potential precipitation of mineral phases in the soil leachates was predicted with PHREEQC-2 (Parkhurst and Appelo, 1999) using the WATEQ4F thermodynamic database (Ball and Nordstrom, 2001) at a temperature of $25^{\circ} \mathrm{C}$

Total soil Se content was obtained by ICP-MS analyses following microwave digestion (Floor et al., 2009). The total major element content in the soil samples was determined by X-Ray Fluorescence (XRF, 

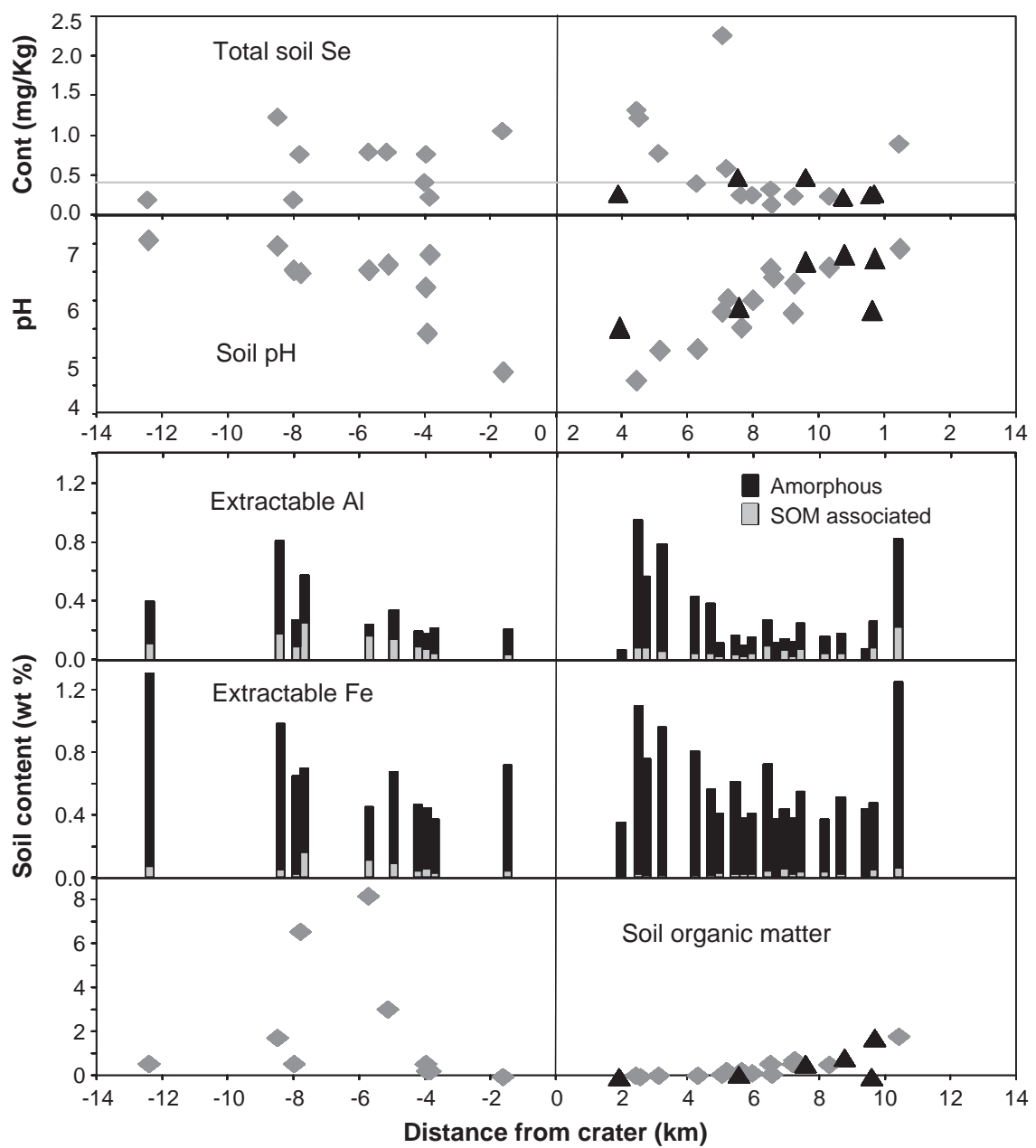

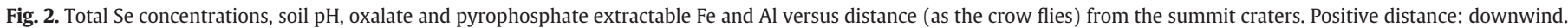
Negative distance: upwind. Triangles: in volcanic plume $\left(90-150^{\circ}\right)$. Diamonds: out volcanic plume. Grey line $=$ worldwide average soil Se concentration (Fonovcs, 2005$)$.

Actlab laboratories Canada). The organic matter concentration was measured by a carbon combustion analyzer (Horiba EMIA-820 V). In order to determine the mineralogy a combination of techniques was used: X-ray Diffraction (XRD, Siemens D5000), Fourier Transform Infrared spectroscopy (FTIR, Bruker Equinox IFS55) and Selective Dissolution Techniques (SDT). For the latter, $100 \mathrm{~mL}$ of ammonium oxalate-oxalic acid $(\mathrm{pH}=3)$ or $0.1 \mathrm{M}$ sodium-pyrophosphate $(\mathrm{pH}=10)$ was put in contact with $1 \mathrm{~g}$ soil overnight to release the amorphous and organic matter bound $\mathrm{Al}$ and Fe respectively (GarcíaRodeja et al., 2007). Afterwards, solutions were centrifuged, filtered and $\mathrm{Si}, \mathrm{Al}$ and Fe were determined using ICP-AES.

\section{Results}

\subsection{Soil properties}

Total Se concentrations varied between 0.12 and $2.25 \mathrm{mg} / \mathrm{kg}$ with a median value of $0.39(n=30$, Fig. 2, Table A1). Half of the samples had concentrations above the worldwide average total Se soil concentration of $0.4 \mathrm{mg} / \mathrm{kg}$ (Fonovcs, 2005). There was no relationship between the Se content and the distance from the crater. Additionally, no Se enrichment was present for samples in the area towards the plume is normally dispersed (Fig. 2). The soil pH varied between 4.6 and 7.0 with an average value of 6.1. Soils close to the volcano showed a lower pH, both upwind and downwind from the summit craters (Fig. 2).

Because adsorption processes play a key role in the Se mobility, Al and Fe compounds have been characterized in the soils. Nevertheless, even using the combination of XRD, FTIR and STD to extract amorphous and organic matter associated $\mathrm{Fe}$ and $\mathrm{Al}$, not all soil minerals could be identified. X-ray diffraction analyses indicated the presence of plagioclase, augite, olivine, magnetite and hematite, but showed that a significant part of the soil compounds were amorphous. Allophane was detected with XRD in only some of the samples. Volcanic glass was one of the amorphous compounds, as confirmed by FTIR and the Fe and Al contents in the oxalate SDT (Buurman et al., 1996). There was a high variation of oxalate extractable $\mathrm{Al} / \mathrm{Si}$ ratios (0.6-1.6 (Table A1)). Moreover, amorphous (oxalate extractable) Al and Fe contents showed a great variability (standard deviations between 43 and 80\%), whereas total $\mathrm{Fe}$ and $\mathrm{Al}$ concentrations were very similar in all soils (standard deviation $<10 \%$ ).

Downwind of the summit vents soil organic matter (SOM) increased with distance from undetectable close to the crater up to almost $2 \%$ at around $10 \mathrm{~km}$ distance. Upwind from the volcano SOM contents were higher (up to $8 \%$ ) and did not show a specific pattern with distance. Samples rich in SOM showed higher percentages of Al and Fe associated with organic matter (pyrophosphate-extractable, Fig. 2, Table A1), although amorphous Al was dominant in almost all soils. There was no correlation between total Se content and SOM.

\subsection{Leaching experiments}

The experiments performed with the soils collected on the flanks of Mount Etna and synthetic Se-free acid rain $(\mathrm{pH}=2)$ showed that the amount of leached Se increased with proximity to the crater 


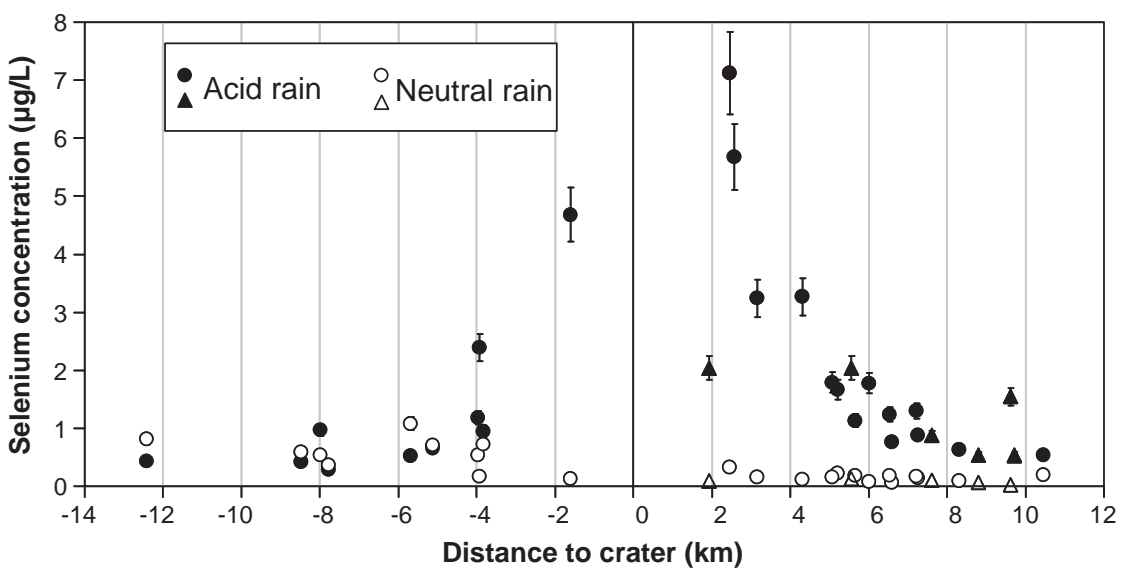

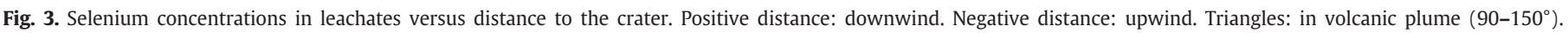
Diamonds: out volcanic plume.

(Fig. 3). The highest Se leachate concentrations (up to $8 \mu \mathrm{g} / \mathrm{L}$ ) were detected during acid rain-soil experiments performed on two downwind sites close to the craters. Leachates from soil samples collected at an altitude below $2000 \mathrm{~m}$ have Se leaching concentrations $<2 \mu \mathrm{g} / \mathrm{L}$, whereas samples from higher altitudes have Se concentrations $>2 \mu \mathrm{g} / \mathrm{L}$ in their leachates. The fraction of the total Se concentration mobilized during acid rain interaction ranged from 0.2 to $4.3 \%$. This means that the patterns of mobilized Se (Fig. 3 ) were different compared to those of the total Se content (Fig. 2).

In contrast to acid-rain experiments, neutral-rain experiments $(\mathrm{pH}=6)$ soil displayed no apparent trends with the distance from the craters, but did show a difference between downwind and upwind samples (Fig. 3). Under neutral conditions a lower percentage of the total soil Se was mobilized compared with acid-rain interaction. For neutral rain between 0.05 and $2.3 \%$ Se was released and as a consequence leaching concentrations were $<2 \mu \mathrm{g} / \mathrm{L}$ in all cases.

Comparing the leachable Se in acid and neutral conditions a very different Se behaviour was observed for soil samples collected downwind close to the craters relative to samples taken upwind, or downwind at greater distance from the volcano. Because triplicate experiments for some selected soils showed variations below $10 \%$, these differences cannot be explained by experimental errors. Samples close to the crater presented significantly higher Se mobilization during acid conditions compared to neutral conditions. However, for the samples further away from the craters Se mobilization was less pH-dependent and in a few cases even showed higher Se leaching at neutral $\mathrm{pH}$. In addition, leachate concentrations were higher upwind than downwind from the volcano after neutralrain interaction (Fig. 3).

The $\mathrm{Al}$ and $\mathrm{Fe}$ concentrations in leachates showed significant variations (e.g. respectively a standard deviation of 52 and 95\% in acid leachates, Table A1). High concentrations of dissolved Al and Fe in the acid leachates were observed (up to 127 and $36 \mathrm{mg} / \mathrm{kg}$, respectively). In general samples from high altitudes $(>2100 \mathrm{~m}$ ) had high Al concentrations in acid leachates ( $>85 \mathrm{mg} / \mathrm{kg}$ ), whereas most samples from below $2100 \mathrm{~m}$ had $\mathrm{Al}$ concentrations less than $85 \mathrm{mg} / \mathrm{kg}$. Synthetic volcanic glass with the same bulk composition as soils showed very low dissolution $(<0.5 \%)$ under the same experimental conditions. Thermodynamic calculation predicts that all final leaching solutions were undersaturated with respect to solid phases, such as poorly ordered Al and Fe minerals (Table A1). Even if the highest Al concentration in the leaching solution (Fig. 4) corresponded with the sample rich in amorphous compounds (Fig. 2), there was no correlation between the Fe and Al concentrations in acid leachates and SDT extractions.

A positive correlation existed between aluminium ( $\mathrm{Al})$ and $\mathrm{Se}$ in the acid leachates (best fit exp law $R^{2}=0.73$ : Fig. 4), whereas no trend between iron ( $\mathrm{Fe}$ ) and Se (best fit power law $\mathrm{R}^{2}=0.32$ ) was detected. However, a relationship was observed between soil pH and acid leachable Se $\left(\mathrm{R}^{2}=0.84\right.$, Fig. 5). There was also a negative correlation between SOM and leached Se under acid conditions (power $\mathrm{R}^{2}=0.7$, Fig. 5). During neutral rain experiments major element composition, $\mathrm{pH}$ or SOM lacked any trend with Se mobilization.

The behaviour of Se is often compared with arsenic (As). For all acid leachates no correlation was observed between the two elements

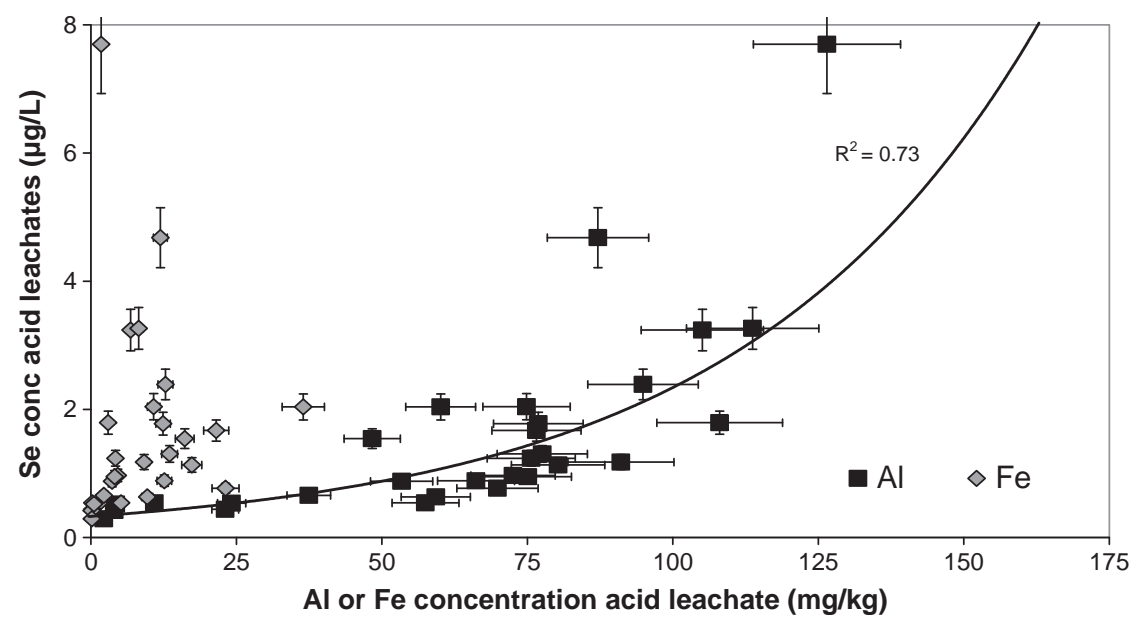

Fig. 4. Relation between acid Se leaching concentration and respectively $\mathrm{Al}$ and Fe leaching concentrations. 


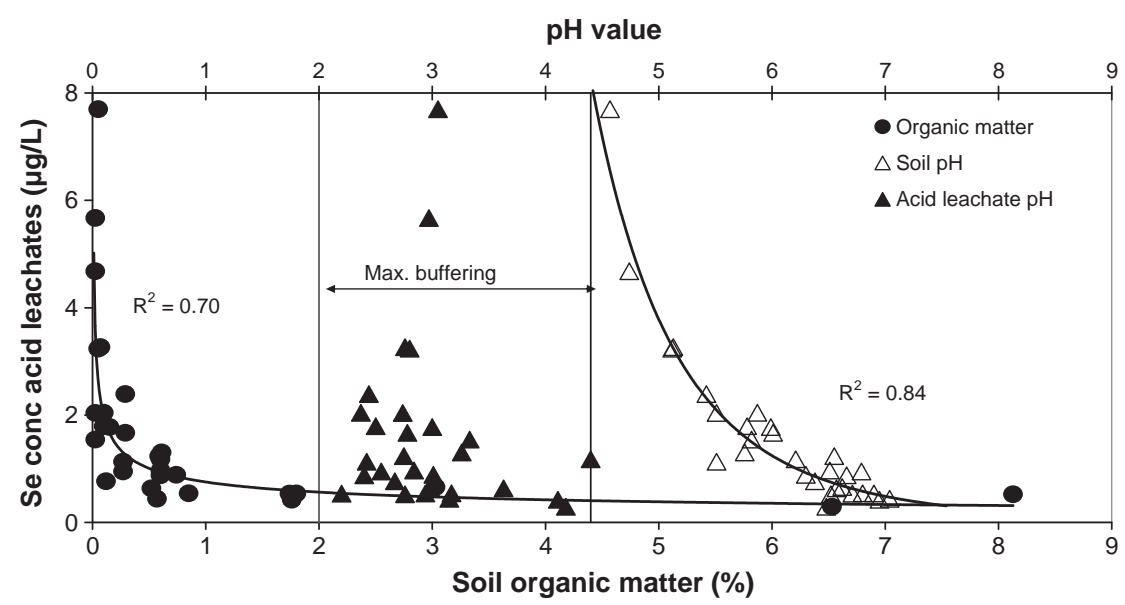

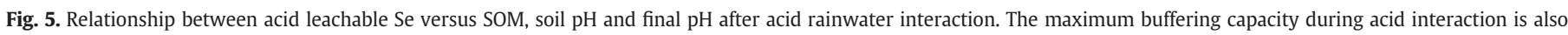
indicated. (Start synthetic acid rain has $\mathrm{pH}=2$ ).

$\left(\mathrm{R}^{2}=0.14\right)$. However, as observed in Fig. 6 , taking into account the experiments with samples collected at altitudes lower than $2100 \mathrm{~m}$ a good correlation between As and Se was present $\left(R^{2}=0.84\right)$.

\section{Discussion}

\subsection{Plume trace element deposition}

Volcanic emissions are a main geogenic point source for Se. It has been shown that both dry and wet deposition can have a significant influence on soils exposed to a volcanic plume (Delmelle et al., 2001, 2003; Delfosse et al., 2005, 2006; Bellomo et al., 2007). However, in the Etnean case trace element deposition from the plume can be excluded as the main process controlling the Se concentrations in the leachates. The volcanic plume is normally dispersed towards the southeast due to the dominant NW wind direction (Fig. 1). Nevertheless, the quantity of mobilized Se in lab controlled experiments is independent of the radial angle of the soil sample location with the main direction of the plume. For example, similar Se distribution patterns are observed upwind and downwind from the crater in acidrain experiments. Moreover, the acid leachates with most regular plume deposition (triangles, Fig. 3) do not show higher Se mobilization compared to leachates from samples not aligned with the main direction of the plume (circles, Fig. 3). Additionally, total soil Se concentrations show no decreasing trend with increasing distance from the summit crater (Fig. 2) that could be related to Se deposition (Calabrese, 2009). Furthermore, there is no correlation in the leachates between Se and other elements strongly enriched in the plume (Calabrese, 2009) and in plant leaves (Martin et al., 2009, 2010), such as Thallium (TI) and Cadmium (Cd) (Table A1, $\mathrm{R}^{2}=0.11$ and 0.02 respectively). The influence of the volcanic Se emissions has been clearly demonstrated in the rainwater Se concentrations (Calabrese, 2009). On the contrary neither the amount of Se mobilized during acid rain-soil interaction nor the total Se soil contents are positively correlated to the Se deposition from the volcanic plume. This shows the importance of soils as reactive interfaces. However, since the plume affects the $\mathrm{pH}$ of the precipitation, volcanic activity still indirectly controls Se mobility in the soil environment.

In the case of soil $\mathrm{pH}$ a similar distribution pattern is observed independent from the radial angle with the main direction of the plume (Fig. 2). This is in contrast with previous work at Masaya volcano (Nicaragua) where soil pHs are consistently lower for sites directly exposed to the volcanic acid emissions as compared to the site located on the plume margin (Parnell, 1986; Delmelle et al., 2003). This could be explained by differences in parental material homogeneity or the plume dispersion characteristics. Soil sites at Masaya correspond to two series each developed on homogenous parental material. The samples at Mount Etna have not been collected along the same lava flow. Nevertheless, $\sim 90 \%$ of the volcano's surface is covered by $<10$ ka lavas from Mongibello (Bonaccorso et al., 2004), which may be viewed as "homogeneous" to a fist approximation. On the other hand, the plume dispersion characteristics are different for both volcanoes. Wind directions are more variable around Etna than at Masaya (Allen et al., 2000; Martin et al., 2009, 2010). Additionally, the sites at Masaya are at approximately the same altitude of the plume vent, so direct plume fumigation occurs regularly increasing

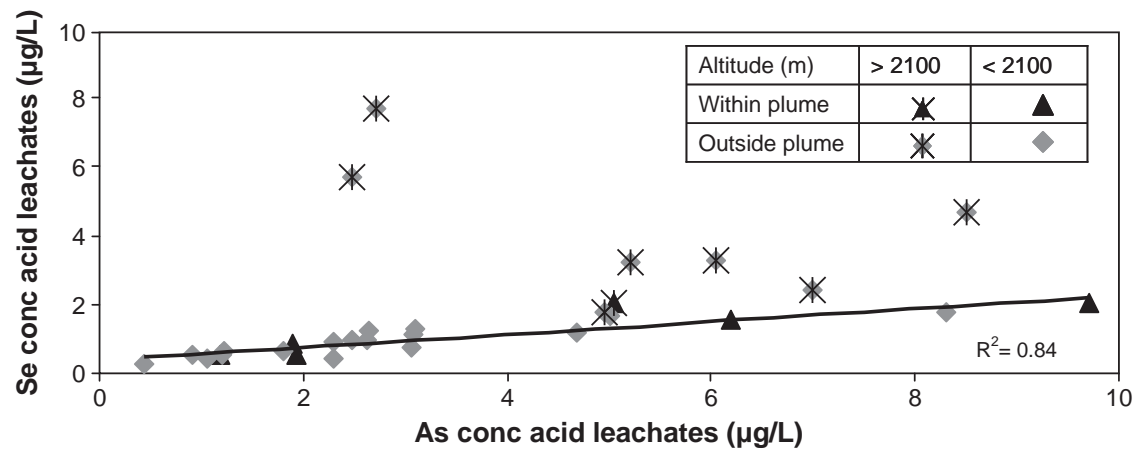

Fig. 6. Comparison between Se and As concentrations in acid soil leachates. 


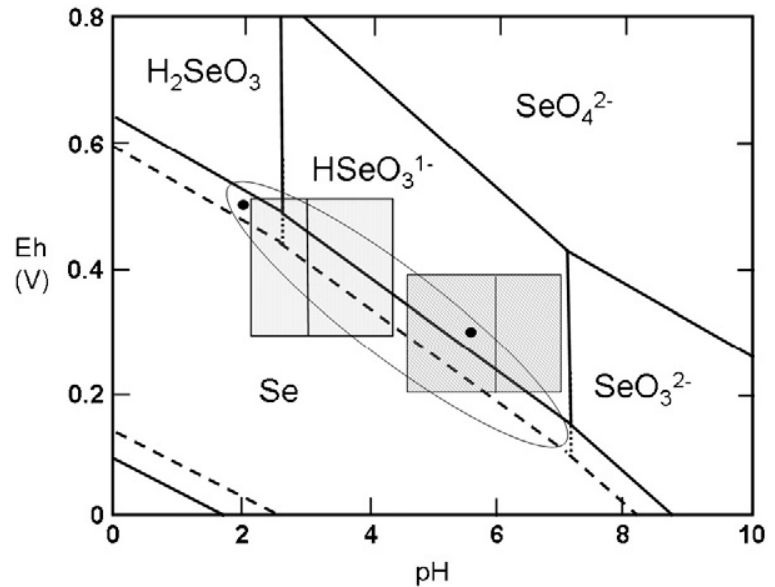

Fig. 7. Part of the Eh-pH diagram of Se-O-H system at $25^{\circ} \mathrm{C}$ and 1 bar pressure (Brookins, 1988 ) indicating the thermodynamic stable Se speciation in our experimental conditions (grey boxes). Solid lines: for $10^{-6} \mathrm{M}$ selenium $(\sim 0.1 \mu \mathrm{g} / \mathrm{L})$. Dashed lines indicate changes in fields for lower Se concentrations. Oval indicates expected $\mathrm{Eh}-\mathrm{pH}$ field for the rainwater (Liotta et al., 2006), squares show the field of our experiments after $4 \mathrm{~h}$ of rain interaction.

the deposition of acidic compounds (Delmelle et al., 2001). In contrast Mount Etna has a conical form with the plume vents at the top. This geometry does not allow frequent direct fumigation of its flanks significantly reducing the deposition of acidic compounds.

\subsection{Influence of $\mathrm{pH}$}

The pH controls surface charges of soil compounds (Yu, 1997; Barrow and Whelan, 1989), mineral dissolution (Oelkers and Gislason, 2001) and Se speciation and protonization. Therefore, this parameter plays a determining role in Se sorption processes (Yu, 1997; Barrow and Whelan, 1989). As discussed in Section 4.2, the rainwater $\mathrm{pH}$ controlled the Se release (Fig. 3). However, the resulting $\mathrm{pH}$ during soil-rain interaction is strongly influenced by the soil characteristics. The soil pH is controlled by the protonation of organic matter and variable charge minerals (Herre et al., 2007). Indeed, we observe some trends with soil characteristics. All soil samples with a soil organic matter content $>1 \%$, have a pH between 6.5 and 7 . Samples with a crystalline Al content (oxalate extractable minus pyrophosphate extractable) $>0.3 \mathrm{wt}$.\% have a $\mathrm{pH}<6.5$. The buffering capacity of soil also depends on the dissolution of allophane, iron oxides, primary silicate minerals and volcanic glass (Herre et al., 2007), as occurring under acid conditions (Fig. 5). However, there was no correlation between mobilized Se and the resulting $\mathrm{pH}$ after acid rain-soil interaction (Fig. 5). This shows that $\mathrm{pH}$ is not the controlling parameter in the Se behaviour in the leachates. Nevertheless, there is a strong positive relationship between soil $\mathrm{pH}$ and acid rain leachable Se $\left(R^{2}=0.84\right.$, Fig. 5$)$. This can be explained by the control of SOM and variable-charge Fe and $\mathrm{Al}$ minerals on both soil $\mathrm{pH}$ and Se release (see discussion later).

\subsection{Role of organic matter}

Soil organic matter has been shown to play a fundamental role in soil Se availability (Gustafsson and Johnsson, 1992). Climate has a strong influence on SOM (Egli et al., 2007) which on Mount Etna is controlled by altitude, slope direction and dominant winds (Chester et al., 1985). However, the biggest differences in SOM depend on the location with respect to the craters, with higher SOM concentrations upwind from the volcano (Table A1; Fig. 5). This can be explained by the fresh ash input downwind from the volcano that dilutes SOM and prevents soil development. Several mechanisms might be responsible for the decreased Se mobility under acidic conditions in SOM-rich samples. Firstly, there is less mineral dissolution occurring due to the stabilization by SOM (Wang and Mulligan, 2006) as confirmed by lower $\mathrm{Al}$ and Fe leachate concentrations (Table A1). Secondly, new adsorption sites can be formed on humic acid or metal-humus complexes (Kamei-Ishikawa et al., 2007). Lastly, the presence of organic matter decreases the redox potential in the solutions (Wang and Mulligan, 2006) and therefore Se may be transformed into the immobile elemental Se (Bruggeman et al., 2007; Fig. 7). Higher mobilized Se concentrations during neutral compared to acid-rain leaching in distal and upwind samples can be explained by Se redox transformations and surface charge changes. At neutral-rain experiment conditions more samples fall in $\mathrm{pH}$-Eh conditions where

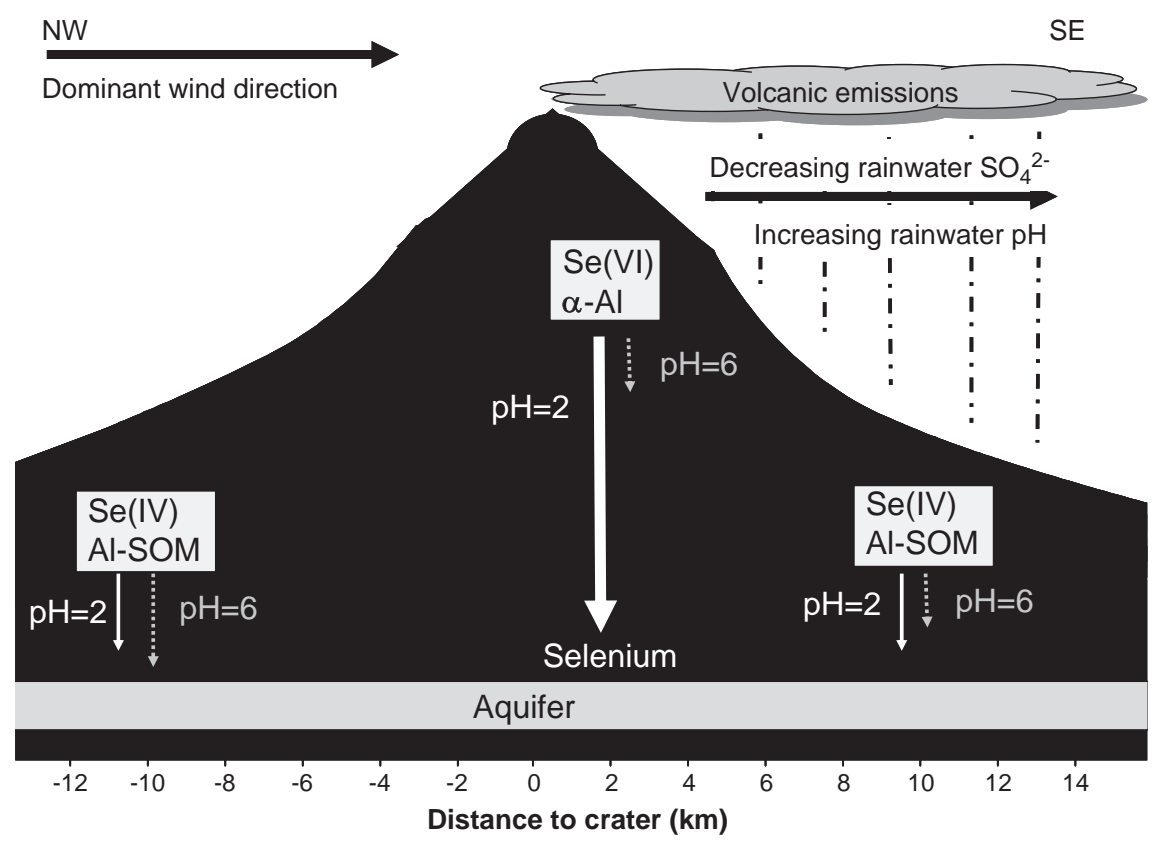

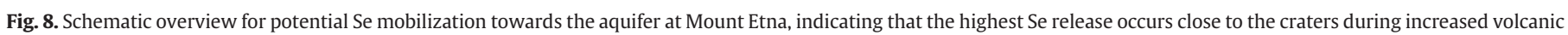
activity. $\mathrm{Se}(\mathrm{VI})=$ selenate, $\mathrm{Se}(\mathrm{IV})=$ selenite. $\mathrm{Al}-\mathrm{SOM}$ are areas where $\mathrm{Al}$ associated with $\mathrm{SOM}$ is present, whereas $\alpha$-Al indicates the high content of amorphous $\mathrm{Al}$ phases. 
selenite $\left(\mathrm{SeO}_{3}^{-1}\right)$ is the thermodynamic species (Fig. 7). Therefore, formation of immobile elemental Se is less favoured. Due to the presence of SOM the Al phases are stable and the Se adsorption will increase at lower $\mathrm{pH}$ due to a higher positive surface charge.

\subsection{Role of $\mathrm{Fe}$ and $\mathrm{Al}$ phases}

Although there is no clear trend in the $\mathrm{Fe}$ and $\mathrm{Al}$ amorphous compound abundance with location, generally the amount of amorphous compounds decreases with increasing distance downwind from the craters. In contrast upwind from the volcano their amount increases with increasing distance (Table A1; Fig. 2). Downwind samples are strongly influenced by fresh ash input and therefore have a low weathering state as evidenced by the higher content of amorphous compounds in the subsoil in samples close to the summit (Egli et al., 2007). However, upwind from the volcano weathering is mainly controlled by climate and follows Alpine characteristics with most intense weathering and consequently less amorphous compounds at higher elevated sites (Mirabella and Egli, 2003). The deviation from these trends between amorphous $\mathrm{Al}$ and Fe content versus the location can be explained by age differences in the parental lava flow and/or differences in the input of fresh pyroclastic material. The higher content of amorphous material at the farthest distance downwind site (Fig. 6) might be related to the agricultural activity on this site. This sample has been taken from a terraced soil. This might help to retain most of the new ash, whereas in natural sites the slope is $>0^{\circ}$ and as a result some of the fresh ash could be mechanically removed. A comparison of the $\mathrm{Fe}$ and $\mathrm{Al}$ concentrations in the acid soil leachates compared with total and oxalate-extractable $\mathrm{Fe}$ and $\mathrm{Al}$ (Table A1) indicated that only a small amount of the Fe is dissolved during the experiment (respectively below 1 and $5 \%$ for total and oxalate-extractable Fe). However, a significant amount of the amorphous $\mathrm{Al}$ is dissolved (up to $43 \%$, average value $18 \%$ ). This cannot be related to volcanic glass dissolution, as volcanic glass with a similar composition as the bulk soils showed low dissolution $(<0.5 \%)$ under the same experimental conditions.

As mentioned earlier, $\mathrm{Fe}$ and $\mathrm{Al}$ phases can present selective adsorption sites, particularly for selenite. Anion adsorption is favourable in acid rain conditions for adsorption sites due to an increasing positive charge of the mineral surface with decreasing $\mathrm{pH}(\mathrm{Yu}, 1997)$. In contrast, higher Se leaching is observed in acid rain conditions (Fig. 8). This can be explained by dissolution of the Al compounds, during which the adsorbed $\mathrm{Se}$ is released too. Rainwater $\mathrm{pH}$ controls the dissolution of such minerals (Oelkers and Gislason, 2001), and thus the selenite release. The high concentrations of dissolved $\mathrm{Al}$ and $\mathrm{Fe}$ in the acid leachates indicate that some soil compounds containing $\mathrm{Al}$, and to a lesser extent $\mathrm{Fe}$, are unstable at low $\mathrm{pH}$. In previous works, Fe oxides are recognized as the main carrier phase of Se in non-volcanic soils (Dhillon and Dhillon, 1999; Fernández-Martínez and Charlet, 2009). However, our results (Fig. 4) support an important role of Al compounds, in agreement with Se studies in Japanese volcanic soils (Nakamaru et al., 2005). The acidic leachates rich in dissolved $\mathrm{Al}$ are those which do not follow the relation between As and Se. As can be observed in Fig. 6, these samples are relatively enriched in Se. This also indicates the active role of $\mathrm{Al}$ phases for the control of Se behaviour in these soils.

Another release mechanism for adsorbed Se during acid rain-soil interaction is the competition for adsorption sites with sulphate $\left(\mathrm{SO}_{4}^{2-}\right)$. The acid rain in the experiments has $450 \mathrm{mg} / \mathrm{L} \mathrm{of} \mathrm{SO}_{4}^{2-}$, corresponding to the maximum $\mathrm{SO}_{4}^{2-}$ concentration measured in rainwater samples in the 2006-2007 period (Calabrese, 2009; Calabrese et al., submitted). Sulphate is especially competitive with selenate for adsorption sites (Wu et al., 2000). Therefore, in this case rain $\mathrm{SO}_{4}^{2-}$ concentration will be a key parameter controlling desorption of selenate $\left(\mathrm{SeO}_{4}^{-2}\right)$. For this reason speciation can be used to obtain a better insight in the mobilization mechanism. Speciation analyses with a low pH mobile phase showed the dominance of selenate in the selenium enriched acid leachates (Floor et al., 2011). This indicates that sulphate competition is a more significant release process than dissolution of the amorphous $\mathrm{Al}$ compounds. Additional experiments with sulphate-containing neutral rain confirmed the role of sulphate in the selenate release (Floor et al., 2011). This mechanism is also perfectly able to explain the differences between As and Se behaviour in these conditions. It was observed that As and Se have different mobility for the soils within $5 \mathrm{~km}$ of the craters and $>2100 \mathrm{~m}$ altitude. These are also the samples which were rich in selenate. This indicates that sulphate does not compete with As anions for adsorption sites. As a result, Se and As do behave differently in samples collected at high altitudes during acid rain-soil interaction (Fig. 6).

\subsection{Se mobility during rain-soil interaction}

In this study it was shown that acid rain can mobilize Se within the volcanic soils. In Fig. 8, a schematic overview of the main results and the controlling processes is given. The results indicate that three different mechanisms control Se mobilization towards the aquifer; rainwater composition (influenced by the volcanic activity), the soil characteristics (especially the Al phases and SOM) and speciation. Selenium is most likely mobilized during increased volcanic activity at sites downwind and close to the craters for three reasons (Fig. 8). Firstly, the interaction of rain with the volcanic plume results in sulphate rich rain close to the crater, but the $\mathrm{SO}_{4}$ - concentration decreases with increasing distances (Aiuppa et al., 2006). Secondly, the soils close to the crater release high levels of Se during acid rain events, which is related to the reactive dissolution Al phases present in the soil. Thirdly, re-adsorption is unlikely given the dominance of selenate (Su and Suarez, 2000; Duc et al., 2003). Upwind and downwind further away from the crater only a small amount of Se will be leached, because at these locations rainwater will be neutral, sulphate-poor and soil properties prevent significant Se mobilization.

The Se mobilization during acid rain-soil interaction might produce natural leaching from volcanic sources to aquifers. With reference to previous work on the vertical displacement of dissolved Se due to rainwater infiltration in non-volcanic seleniferous soils (Dhillon et al., 2008), higher Se mobilization occurred in the Etnean field site. In this study natural desorption of Se was studied. Taking into account that acid rain normally contains Se (Calabrese, 2009; Calabrese et al., submitted), the effect can be amplified. Future work should quantify the Se flux related to this mechanism.

\section{Conclusions}

Acid rain-soil interaction was identified as a geogenic process which can mobilize Se. This might potentially produce natural leaching from volcanic sources to aquifers, which can have significant impact on human health, as $10 \%$ of the worlds' population lives within $100 \mathrm{~km}$ of an active volcano (Small and Naumann, 2001). Similarly, anthropogenic acid rain could trigger large scale mobilization in contaminated soils with even more dramatic consequences for water quality and human health.

In the case of Etna volcano, fluxes of trace element deposition from the plume do not directly correlate with Se mobilization during soil-rain interaction. This highlights the importance of soils as reactive interfaces. Soil composition and mineralogy, especially the presence of $\mathrm{Al}$ compounds, control the quantity of Se mobilized. Selenium adsorbed onto these solid phases can be released by competition of adsorption sites with sulphate in the case of selenate, or by mineral dissolution enhanced by the low rainwater $\mathrm{pH}$ for selenite. Sulphate competition was identified as the main mobilization mechanism. Soil organic matter (SOM) also plays a role since it stabilizes Al compounds, can form Se adsorption sites and allows redox transformations to elemental Se. As a result, less Se is mobilized under acid conditions in SOM-rich soils. The competition for adsorption sites between sulphate and selenate could also explain the differences between the chemical fate of As and Se. 
The Etnean aquifer has been shown to be enriched in Se. Previously, leaching of the host rock and the input of thermal saline waters from the sedimentary basin have been proposed as the processes controlling the chemical composition of the groundwater (Giammanco et al., 1998; Aiuppa et al., 2000; Brusca et al., 2001). However, in this study it was demonstrated that acid rain can produce Se mobilization within volcanic soils and as a result might represent an additional source of Se to the aquifer. The results show that Se is most likely mobilized towards the aquifer close to the craters when volcanic-derived acid sulphate-containing rain interacts with the poorly developed soils rich in amorphous Al. Moreover, since the leaching solutions are dominated by the presence of selenate, Se is likely to remain in solution and reach the aquifer, because adsorption processes within the soil profile are expected to be low. Our findings clearly show that the contribution of rainwater and sorption processes within the soils should be considered to constrain the Se budget of the aquifer.

The distribution of soil $\mathrm{pH}$ around Etna and Masaya volcano is dissimilar. Given the strong link between soil pH and Se leaching, it would suggest that the Se behaviour could also be different in both systems. Although volcanic environments are often generalized, the results indicate that local dynamics play a key role in the geochemical cycle and that the lack of influence of the volcanic plume in the Se distribution in soils should be evaluated for different volcanoes.

Supplementary data associated with this article can be found, in the online version, at doi:10.1016/j.chemgeo.2011.08.004.

\section{Acknowledgements}

GHF thanks Giovanni Pardini, Mònica Iglesias and everyone from BRGM MMA and the technical service from the UdG. This is a contribution of the AquaTRAIN Marie Curie Research Training Network (Contract No. MRTN-CT-2006-035420) funded under the European Commission Sixth Framework Programme (2002-2006) Marie Curie Actions, Human Resources \& Mobility Activity Area-Research Training Networks. Additional funding was obtained by the research division of BRGM and by INGV-Pa.

\section{References}

Agnelli, A.E., Corti, G., Agnelli, A., Del Carlo, P., Ugolini, F.C., 2007. Features of some paleosols on the flanks of Etna volcano (Italy) and their origin. Geoderma 142 (1-2), 112-126.

Aiuppa, A., Allard, P., D'Alessandro, W., Michel, A., Parello, F., Treuil, M., Valenza, M. 2000. Mobility and fluxes of major, minor and trace metals during basalt weathering and groundwater transport at Mt. Etna volcano (Sicily). Geochimica et Cosmochimica Acta 64 (11), 1827-1841.

Aiuppa, A., Dongarrà, G., Valenza, M., Federico, C., Pecoraino, G., 2003a. Degassing of trace volatile metals during the 2001 eruption of Etna. Geophysical Monograph $139,41-54$.

Aiuppa, A., Bellomo, S., Brusca, L., D'Alessandro, W., Federico, C., 2003b. Natural and anthropogenic factors affecting groundwater quality of an active volcano (Mt. Etna, Italy). Applied Geochemistry 18 (6), 863-882.

Aiuppa, A., Bellomo, S., D’Alessandro, W., Federico, C., Ferm, M., Valenza, M., 2004 Volcanic plume monitoring at Mount Etna by diffusive (passive) sampling. J. Geophys. Res. 109

Aiuppa, A., Bellomo, S., Brusca, L., D'Alessandro, W., Di Paola, R., Longo, M., 2006. Major ion bulk deposition around an active volcano (Mt. Etna, Italy). Bulletin of Volcanology 68, 255-265

Allard, P., Jean-Baptiste, P., D'Alessandro, W., Parello, F., Parisi, B., Flehoc, C., 1997 Mantle-derived helium and carbon in groundwaters and gases of Mount Etna, Italy. Earth and Planetary Science Letters 148, 501-516.

Allen, A.G., Baxter, P.J., Ottley, C.J., 2000. Gas and particle emissions from Soufrière Hills Volcano, Montserrat, West Indies: characterization and health hazard assessment. Bulletin of Volcanology 62 (1), 8-19.

Andronico, D., Cristaldi, A., 2007. Il parossismo del 23-24 novembre 2007 al Cratere di SE: caratteristiche del deposito di caduta. http://www.ct.ingv.it/Report/RPTVETCEN 20071123.pdf.

Andronico, D., Scollo, S., Cristaldi, A., Caruso, S., 2008a. The 2002-03 Etna explosive activity: tephra dispersal and features of the deposit. Journal of Geophysical Research. doi:10.1029/2007JB005126.

Andronico, D., Cristalli, A., Scollo, S., 2008b. The 4-5 September 2007 lava fountain at South-East Crater of Mt Etna, Italy. Journal of Volcanology and Geothermal Research $173,325-328$.

Balistrieri, L.S., Chao, T.T., 1990. Adsorption of selenium by amorphous iron oxyhydroxide and manganese dioxide. Geochimica et Cosmochimica Acta 54, 739-752.
Ball, J.W., Nordstrom, D.K., 2001. User's manual for WATEQ4F with revised thermodynamic database and test cases for calculating speciation of major, trace and redox elements in natural waters. U.S. Geological Survey Water-Resources Investigation Report, pp. 91-183.

Barrow, N.J., Whelan, B.R., 1989. Testing a mechanistic model. VII. The effects of $\mathrm{pH}$ and of electrolyte on the reaction of selenite and selenate with a soil. Journal of Soil Science 40 (1), 17-28.

Bellomo, S., D'Alessandro, W., Longo, M., 2003. Volcanogenic fluorine in rainwater around active degassing volcanoes: Mt. Etna and Stromboli Island, Italy. Science of the Total Environment 301 (1-3), 175-185.

Bellomo, S., Aiuppa, A., D'Alessandro, W., Parello, F., 2007. Environmental impact of magmatic fluorine emission in the Mt. Etna area. Journal of Volcanology and Geothermal Research 165 (1-2), 87-101.

Bonaccorso, A., Calvari, S., Coltelli, M., Del Negro, C., Falsaperla, S. (Eds.), 2004. Mt. Etna: volcano laboratory. American Geophysical Union: Geophysical Monograph, 143, pp. 1-369.

Brookins, D.G., 1988. Eh-pH Diagrams for Geochemistry. Springer-Verlag, Berlin.

Bruggeman, C., Maes, A., Vancluysen, J., 2007. The interaction of dissolved boom clay and gorleben humic substances with selenium oxyanions (selenite and selenate). Applied Geochemistry 22, 1371-1379.

Brusca, L., Aiuppa, A., D'Alessandro, W., Parello, F., Allard, P., Michel, A., 2001. Geochemical mapping of magmatic gas-water-rock interactions in the aquifer of Mount Etna volcano. Journal of Volcanology and Geothermal Research 108 (1-4), 199-218.

Buurman, P., van Lagen, B., Velthorst, E.J., 1996. Manual for Soil and Water Analysis. Backhuys Publishers, Leiden, Netherlands.

Byers, H.G., Miller, J.T., Williams, K.T., Lakin, H.W., 1938. Selenium occurrence in certain soils in the United States with a discussion of related topics. Third Report U.S.D.A. Tech Bul, p. 601.

Calabrese, S., 2009. Atmospheric deposition of volcanogenic major and trace elements on Mt. Etna, Sicily. PhD Dissertation, University of Palermo, Italy.

Calabrese, S., Aiuppa, A., Allard, P., Bagnato, E., Brusca, L., D'Alessandro, W., Parello, F., submitted. Atmospheric sources and sinks of volcanogenic elements in a basaltic volcano (Etna, Italy). Geochimica et Cosmochimica Acta.

Certini, G., Fernandez Sanjurjo, M.J., Corti, G., Ugolini, F.C., 2001. The contrasting effect of broom and pine on pedogenic processes in volcanic soils (Mt. Etna, Italy). Geoderma 102 (3-4), 239-254.

Chester, D.K., Duncan, A.M., Guest, J.E., Kilburn, C.R.J., 1985. Mount Etna: the Anatomy of a Volcano. Chapman and Hall, London.

D'Alessandro, W., Giammanco, S., Parello, F., Valenza, M., 1997. CO2 output and 13C (CO2) from Mount Etna as indicators of degassing of shallow asthenosphere. Bulletin of Volcanology 58, 455-458.

Dazzi, C., 2007. Environmental features and land use of Etna (Sicily-Italy). In: Ò Arnalds, O., Bartoli, F., Buurman, P., Òskarsson, H., Stoops, G., Garcia-Rodeja, E. (Eds.), Soils of Volcanic Regions in Europe. Springer, Berlin, pp. 629-644.

Delfosse, T., Delmelle, P., Iserentant, A., Delvaux, B., 2005. Contribution of $\mathrm{SO}_{3}$ to the acid neutralizing capacity of Andosols exposed to strong volcanogenic acid and $\mathrm{SO}_{2}$ deposition. European Journal of Soil Science 56. doi:10.1111/j.1365-2389.2004.00647.x.

Delfosse, T., Delmelle, P., Delvaux, B., 2006. Sulphate sorption at high equilibrium concentration in Andosols. Geoderma 136 (3-4), 716-722.

Delmelle, P., Stix, J., Bourque, C.P.A., Baxter, PJ., Garcia-Alvarez, J., Barquero, J., 2001. Dry deposition and heavy acid loading in the vicinity of Masaya Volcano, a major sulfur and chlorine source in Nicaragua. Environmental Science and Technology 35, 1289-1293.

Delmelle, P., Delfosse, T., Delvaux, B., 2003. Sulfate, chloride and fluoride retention in Andosols exposed to volcanic acid emissions. Environmental Pollution 126 (3), 445-457.

Dhillon, K.S., Dhillon, S.K., 1999. Adsorption-desorption reactions of selenium in some soils of India. Geoderma 93 (1-2), 19-31.

Dhillon, S.K., Dhillon, K.S., Kohli, A., Khera, K.L., 2008. Evaluation of leaching and runoff losses of selenium from seleniferous soils through simulated rainfall. Journal of Plant Nutrition and Soil Science 171, 187-192.

Duc, M., Lefevre, G., Fedoroff, M., Jeanjean, J., Ruchard, J.C., Monteil-Rivera, F., Dumenceau, J., Milonjic, S., 2003. Sorption of selenium anionic species on apatites and iron oxides from aqueous solutions. Journal of Environmental Radioactivity 70, 61-67.

Dynes, J.J., Huang, P.M., 1997. Influence of organic acids on selenite sorption by poorly ordered aluminium hydroxides. Soil Science Society of America Journal 61, $772-783$.

Egli, M., Alioth, L., Mirabella, A., Raimondi, S., Nater, M., Verel, R., 2007. Effect of climate and vegetation on soil organic carbon, humus fractions, allophanes, imogolite, kaolinite, and oxyhydroxides in volcanic soils of Etna (Sicily). Soil Science 172 (9), 673-691 (2007)

Faivre-Pierret, R., Le Guern, F., 1983. Health risks linked with inhalation of volcanic gases and aerosols. In: Tazief, H., Sabroux, J.C. (Eds.), Forecasting Volcanic Events. Elsevier, Amsterdam, pp. 69-81.

Fernández-Martínez, A., Charlet, L., 2009. Selenium environmental cycling and bioavailability: a structural chemist point of view. Reviews in Environmental Science and Biotechnology 8, 81-110.

Floor, G.H., Iglesias, M., Roman-Ross, G., 2009. Selenium determination in volcanic soils by ICP-QMS: influence of reaction cell pressurization and methanol addition on the occurrence of spectral interferences. Journal of Analytical Atomic Spectrometry 24, 944-948.

Floor, G.H., Lenz, M., Iglesías, M., Román-Ross, G., Corvini, Ph., 2011. Selenium speciation in acidic environmental samples: application to acid rain-soil interaction at Mount Etna volcano. Chemosphere 81, 1164-1670. doi:10.1016/j.chemosphere.2011.05.006.

Fonovcs, F., 2005. Chapter 15: Selenium, In: Selinus, O. (Ed.), Essentials of Medical Geology, 1st edn. Elsevier, Amsterdam, pp. 373-415. 
García-Rodeja, E., Nóvoa, J.C., Pontevedra, X., Martínez-Cortizas, A., Buurman, P., 2007. Aluminium and iron fractionation of European volcanic soils by selective dissolution techniques. In: Ò Arnalds, O., Bartoli, F., Buurman, P., Òskarsson, H., Stoops, G., Garcia-Rodeja, E. (Eds.), Soils of Volcanic Regions in Europe. Springer, Berlin, pp. 325-351.

Gauthier, P.J., Le Cloarec, M.F., 1998. Variability of alkali and heavy metal fluxes released by Mt. Etna volcano, Sicily, between 1991 and 1995. Journal of Volcanology and Geothermal Research 81 (3-4), 311-326.

Giammanco, S., Valenza, M., Pignato, S., Giammanco, G., 1996. Mg, Mn, Fe, and V concentrations in the ground waters of Mount Etna (Sicily). Water Research 30 (2), $378-386$.

Giammanco, S., Ottaviani, M., Valenza, M., Veschetti, E., Principio, E., Giammanco, G., Pignato, S., 1998. Major and trace elements geochemistry in the ground waters of a volcanic area: Mount Etna (Sicily, Italy). Water Research 32 (1), 19-30.

Gustafsson, J.P., Johnsson, L., 1992. Selenium retention in the organic matter of Swedish forest soils. Journal of Soil Science 43, 461-472.

Herre, A., Lang, F., Siebe, C., Dohrmann, R., Kaupenjohann, M., 2007. Mechanisms of acid buffering and formation of secondary minerals in vitric Andosols. European Journal of Soil Science 58 (2), 431-444.

Hinkley, T.K., Lamothe, P.J., Wilson, S.A., Finnegan, D.L., Gerlach, T.M., 1999. Metal emissions from Kilauea and a suggested revision of the estimated worldwide metal output by quiescent degassing of volcanoes. Earth Planet Sci. Lett. 170 (3), 315-325.

INGV-Ct, 2008. Mt. Etna eruptive activity report UFVG2008/043. http://193.206.223.22/ Report/RPTVETCEN20080510.pdf.

John, M.K., Saunders, W.M.H., Watkinson, J.H., 1975. Selenium adsorption by New Zealand soils I. Relative adsorption of selenite by representative soils and their relationship to soil properties. New Zealand Journal of Agricultural Research 19, 143-151.

Kamei-Ishikawa, N., Tagami, K., Uchida, S., 2007. Sorption kinetics of selenium on humic acid. Journal of Radioanalytical and Nuclear Chemistry 274 (3), 555-561.

Liotta, M., Brusca, L., Grassa, F., Inguaggiato, S., Longo, M., Madonia, P., 2006. Geochemistry of rainfall at Stromboli volcano (Aeolian Islands): isotopic composition and plume-rain interaction. Geochemistry, Geophysics, Geosystems 7Q07006. doi:10.1029/ 2006GC001288.

Martin, R.S., Mather, T.A., Pyle, D.M., Watt, S.F.L., Day, J.A., Collins, S.J., Wright, T.E., Aiuppa, A., Calabrese, S., 2009. Sweet chestnut (Castanea sativa) leaves as a bioindicator of volcanic gas, aerosol and ash deposition onto the flanks of Mt Etna in 2005-2007. Journal of Volcanology and Geothermal Research 179 (1-2), 107-119.

Martin, R.S., Mather, T.A., Pyle, D.M., Day, J.A., Witt, M.L.I., Collins, S.J., Hilton, R.G., et al., 2010. Major and trace element distributions around active volcanic vents determined by analyses of grasses: implications for element cycling and biomonitoring. Bulletin of Volcanology 72 (8), 1009-1020.

Mather, T.A., Pyle, D.M., Oppenheimer, C., 2003. Tropospheric volcanic aerosol. Geophys Monogr 139. In: Robock, A., Oppenheimer, C. (Eds.), Volcanism and the Earth's Atmosphere, pp. 189-212.

Mirabella, A., Egli, M., 2003. Structural transformations of clay minerals in soils of a climosequence in an Italian alpine environment. Clays and Clay Minerals 51, 264-278.
Monahan-Pendergast, M., Przybylek, M., Lindblad, M., Wilcox, J., 2008. Atmospheric Environment 42 (10), 2349-2357.

Nakamaru, Y., Tagami, K., Uchida, S., 2005. Distribution coefficient of selenium in Japanese agricultural soils. Chemosphere 58 (10), 1347-1354.

Oelkers, E.H., Gislason, S.R., 2001. The mechanism, rates and consequences of basaltic glass dissolution: I. An experimental study of the dissolution rates of basaltic glass as a function of aqueous $\mathrm{Al}, \mathrm{Si}$ and oxalic acid concentration at $25^{\circ} \mathrm{C}$ and $\mathrm{pH}=3$ and 11. Geochimica et Cosmochimica Acta 65 (21), 3671-3681.

Parida, K.M., Gorai, B., Das, N.N., Rao, S.B., 1997. Studies on ferric oxide hydroxides 3. Adsorption of selenite $\left(\mathrm{SeO}_{3}^{2-}\right)$ on different forms of iron oxyhydroxides. Journal of Colloid and Interface Science 185, 355-362.

Parkhurst, D.L., Appelo, C.A.J., 1999. PHREEQC2 User's Manual and Program. US Geological Survey.

Parnell, R.A., 1986. Processes of soil acidification in tropical durandepts, Nicaragua. Soil Science $42,43-55$

Peak, D., Saha, U.K., Huang, P.M., 2006. Selenite adsorption mechanisms on pure and coated montmorillonite: an EXAFS and XANES spectroscopic study. Soil Science Society of America Journal 70 (1), 192-203.

Rayman, M.P., 2000. The importance of selenium to human health. Lancet 356 (9225), 233-241.

Scollo, S., Del Carlo, P., Coltelli, M., 2007. Tephra fallout of 2001 Etna flank eruption: analysis of the deposit and plume dispersion. Journal of Volcanology and Geothermal Research 160, 147-164.

Shoji, S., Nanzyo, M., Dahlgren, R.A., 1993. Volcanic Ash Soils: Genesis, Properties, and Utilization. Elsevier Sci. Pub., Amsterdam, The Netherlands. 288 pp.

Small, C., Naumann, T., 2001. The global distribution of human population and recent volcanism. Global Environmental Change B 3, 93-109.

Su, C., Suarez, D.L., 2000. Selenate and selenite sorption on iron oxides: an infrared and electrophoretic study. Soil Science Society of America Journal 64 (1), 101-111.

Suzuoki, T., 1964. A geochemical study of selenium in volcanic exhalation and sulfur deposits. Bulletin of the Chemical Society of Japan 37, 1200-1206.

Symonds, R.B., Reed, M.H., 1993. American Journal of Science 293, 758-864.

Tanguy, J.C., Condomines, M., Kieffer, G., 1997. Evolution of the Mount Etna magma: constraints on the present feeding system and eruptive mechanism. Journal of Volcanology and Geothermal Research 75, 221-250.

Wang, S., Mulligan, C.N., 2006. Effect of natural organic matter on arsenic release from soils and sediments into groundwater. Environmental Geochemistry and Health 28, 197-214.

Wen, H., Carignan, J., 2007. Reviews on atmospheric selenium: emissions, speciation and fate. Atmospheric Environment 41 (34), 7151-7165.

Wijnja, H., Schulthess, C.P., 2000. Vibrational spectroscopy study of selenate and sulfate adsorption mechanisms on Fe and Al (hydr)oxide surfaces. Journal of Colloid and Interface Science 229, 286-297.

Wu, C.H., Lo, S.L., Lin, C.F., 2000. Competitive adsorption of molybdate, chromate sulfate, selenate, and selenite on $\gamma$-Al2O3. Colloid Surface A 166 (1-3), 251-259.

Yu, T.R., 1997. Chemistry of Variable Charge Soils. Oxford University Press, New York. 